\title{
Essential oil composition of Torilis arvensis subsp. neglecta from Bingöl (Turkey)
}

\begin{abstract}
Plants are a large source of new bioactive molecules with therapeutic potentials. Only a small percentage of living plants on earth have been phytochemically investigated. Many of the Apiaceae taxa have medicinal, aromatic or economical properties and can potentially be used in the industries such as cosmetics, foods, hygienic products, perfumery and they are uses presumed to be connected to the terpenic constituents of the essential oils. Torilis arvensis subsp. neglecta belonging to the Apiaceae family and distributed in Asia, Europe and North Africa. T. arvensis subsp. neglecta has been used in folk medicine for the treatment of gastrointestinal illnesses in Iran and Pakistan. Some Torilis species from Turkey have antioxidant, antimicrobial and antibacterial effects. In addition, the plant is highly effective against some pathogens, thus confirming its use as disinfectant or antiseptic. In this study aerial parts essential oil of T. arvensis subsp. neglecta was analyzed by HS-SPME (Headspace Solid Phase Microextraction), as a result thirty four components were identified. Spathulenol $(29.2 \%), \beta$-farnesene $(18.5 \%)$ and $\beta$-caryophyllene $(10.2 \%)$ were detected the major constituents of the plant. With this study, chemotypes of studied sample was spathulenol, $\beta$-farnesene and $\beta$-caryophyllene. In addition studied plant sample was found to be rich in respect to essential oil. The results discussed natural product, renewable resources and chemotaxonomy.
\end{abstract}

Keywords: Torilis, essential oil, HS-SPME, Apiaceae
Volume 6 Issue 5 - 2018

\author{
Ömer Kiliç \\ Department of Park and Garden Plant, Bingol University, Turkey
}

Correspondence: Ömer Kiliç, Department of Park and Garden Plant, Bingol University, Technical Science Vocational College, Bingol-Turkey, Email omerkilic77@gmail.com

Received: August 16, 2018 | Published:September 14, 2018

\section{Introduction}

Torilis Gaertn. is in the Umbelliferae family and this family has a cosmopolitan spreading, but most of Apiaceae taxa are confined to northern temperate areas, and high altitudes in the tropic regions. ${ }^{1}$ Apiaceae has annual and perennial herbs, rarely shrubby, the leaves are generally alternate, hollow stems, usually exstipulate, the petioles are often large and sheaed at the base, the inflorescence is usually a compound umbel, and the flowers are generally hermaphrodite. ${ }^{2}$ Apiaceae is a large family in terms of number of plants, composed of more than 3.700 species belonging to 434 genera all around the world. ${ }^{3}$ In Turkey this family is represented by about 102 genus and 465 species from which 130 are endemic with a $30 \%$ endemism rate. ${ }^{4-6}$ Plants of this family, generally known as carrot or parsley, are mostly aromatic and medicinally important and, are well known with regard to variability and rich profile of secondary metabolites, especially essential oils. ${ }^{7}$ Apiaceae taxa are rich in respect to secondary metabolites and embodies numerous genera of high economic and medicinal value yielding flavonoids, coumarins, acetylenes, terpenes, essential oils and it is well known that occurrence of essential oils and oleoresins is a characteristic feature of this family. ${ }^{8}$ Taxa of the parsley family are well known with regards to their economic importance, diversity of essential oils ${ }^{7}$ and these plants have particular flavors, odor and are largely used in traditional medicine in many parts of the world. ${ }^{9}$ Herbal and botanical products, such as essential oils and plant extracts, have been studied for their antimicrobial activities. ${ }^{10}$ Essential oils are aromatic oily liquids obtained from different plant parts and have broad activities. Other than antibacterial and antiviral effects, most EOs investigated possess insecticidal, antifungal, acaricidal, cytotoxic and antioxidant properties. ${ }^{11}$ Therefore, they are intensely investigated in the fields of pharmacology, pharmaceutical botany, medical and clinical microbiology, phytopathology and food preservation. They are also widely used as food flavours and preservatives to prevent growth of food-borne bacteria and molds, and so extend the shelf life of processed foods. ${ }^{12}$ Plants of the Apiaceae family possess a range of compounds with many biological activities. Some of the main properties are ability to induce apoptosis, antibacterial, hepatoprotective and vaso-relaxant activities, cyclooxygenase inhibitory effect and antitumor action. ${ }^{13}$

Torilis is a genus of potential use in medicine because of interesting anti-infectious and anticancer properties [14]. It is mainly spreading in the Mediterranean area but distributed also in South and Central Asia. Anatolia is thought to be the main diversity centre for the genus because 11 of these 13 species and also the only endemic species of the genus are found in Anatolia. ${ }^{15}$ Indeed, members of this genus display intraspecific variations like heterocarpy and heterophylly as well as interspecific similarities, thus complicating their classification. There is often confusion between different samples of this genus in herbariums and so the aim of this study is to develop a method to find characters providing data of both taxonomical and pharmaceutical use. Most phytochemical studies on Torilis have focused on terpenoids ${ }^{16}$ so data on flavonoids is limited.

In this study, essential oil composition of Torilis arvensis subsp. neglecta which was collected from Bingöl (Turkey) was undertaken for the first time.

\section{Materials and methods}

\section{Plant material}

T. arvensis subsp. neglecta was collected from Bingöl, vicinity of Sancak waist, stony areas, 1700-1750 m, on May 2018. The taxonomic description of the plant sample was made according to 
volume 4 of Flora of Turkey. ${ }^{2}$ Voucher specimen was deposited in the Bingöl University, Department of Park and Garden Plants.

\section{HS-SPME Procedure}

Dried aerial part powder of five grams plant samples were carried out by a head space solid phase microextraction method using a

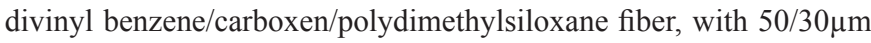
film thickness; before the analysis the fiber was conditioned in the injection port of the gas chromatography (GC) as indicated by the manufacturer. For each sample, $5 \mathrm{~g}$ of plant samples, previously homogenized, were weighed into a $40 \mathrm{ml}$ vial; the vial was equipped with a "mininert" valve. The vial was kept at $35^{\circ} \mathrm{C}$ with continuous internal stirring and the sample was left to equilibratefor $30 \mathrm{~min}$; then, the solid fiber microextraction was exposed for $40 \mathrm{~min}$ to the headspace while maintaining the sample at $35^{\circ} \mathrm{C}$. After sampling, the solid microextraction fiber was introduced into the gas chromatography injector, and was left for $3 \mathrm{~min}$ to allow the analyzes thermal desorption. In order to optimize the technique, the effects of various parameters, such as sample volume, sample headspace volume, sample heating temperature and extraction time were studied on the extraction efficiency as previously reported by Verzera et al. ${ }^{17} \mathrm{~A}$ Varian 3800 gas chromatograph directly inter faced with a Varian 2000 ion trap mass spectrometer was used with injector temperature, $260^{\circ} \mathrm{C}$; injection mode, splitless; column, $60 \mathrm{~m}, \mathrm{CP}-\mathrm{Wax} 52 \mathrm{CB} 0.25 \mathrm{~mm}$ i.d., $0.25 \mathrm{~mm}$ film thickness. The oven temperature was programmed as follows: $45^{\circ} \mathrm{C}$ held for $5 \mathrm{~min}$, then increased to $80^{\circ} \mathrm{C}$ at a rate of $10^{\circ} \mathrm{C} /$ min, and to $240^{\circ} \mathrm{C}$. at $2^{\circ} \mathrm{C} / \mathrm{min}$. The carrier gas was helium, used at a constant pressure of $10 \mathrm{psi}$; the transfer line temperature, $250^{\circ} \mathrm{C}$; the ionisation mode, electron impact (EI); acquisit ion range, 40 to $200 \mathrm{~m} / \mathrm{z}$; scan rate, $1 \mathrm{us}^{-1}$. The compounds were identified using the NIST (National Institute of Standards and Technology) library and verified by the retention indices which were calculated as described by Van den Dool and Kratz. ${ }^{18}$ The relative amounts were calculated on the basis of peak-area ratios. The identified constituents are listed in Table 1.

\section{Results and discussion}

In this study, major compounds of Torilis arvensis subsp. neglecta were spathulenol $(29.2 \%), \beta$-farnesene (18.5\%), and $\beta$-caryophyllene (10.2\%) (Table 1); similarly, $\beta$-caryophyllene was detected as the main compound in different parts of Torilis arvensis stem (4.92\%) and leaves $(8.38 \%) .{ }^{19}$ The leaf and stem essential oils of Torilis arvensis were analyzed and both oils are dominated by trans- $\beta$ farnesene and contained significant amounts of $\beta$-cubebene, cis- $\beta$ farnesene, $\beta$-caryophyllene and nuciferyl acetate $;^{19}$ in our research $\beta$-farnesene $(18.5 \%), \beta$-caryophyllene $(10.2 \%), \beta$-cubebene $(2.2 \%)$ were also detected high percentages (Table 1). It is noteworthy that, sparthulenol was not detected in the essential oil of Torilis arvensis. ${ }^{19}$ More than 25.000 different terpenoids are known; and terpenes play a board range of physiological and ecological roles including, plant primary metabolism, and protection against herbivores and pathogens, attractants for pollinators and as allelopathic agent; other economically important terpenes include cartenoid pigments, natural rubber and the essential oils. ${ }^{20}$ The chemical composition of the essential oil of Torilis arvensis (Huds.) Link. was studied by GC/MS and twenty-two components have been identified, of which (E)- $\beta$-farnesene $(27.7 \%)$ and ar-curcumene (19.5\%) were the major ones. ${ }^{16}$ In this research farnesene was detected major ones, but curcumene not detected (Table 1). In another study, spathulenol (15.7\%) and trans- $\alpha$ bergamotene $(10.4 \%)$ were the main components among the sixty constituents characterized in the oil of aerial parts of Torilis leptophylla representing $91.3 \%$ of the total components detected..$^{21}$ In our research spathulenol $(29.2 \%)$ was detected major ones, but trans- $\alpha$ bergamotene not detected (Table 1). In herbal medicine, the mild sedative properties of hops is due to the presence of $\beta$-caryophyllene; ${ }^{22}$ in vitro studies it was demonstrated the cytotoxic activity of the $\beta$-caryophyllene against breast cancer cells..$^{23}$ In our study $\beta$-caryophyllene was determined in high amount from $T$. arvensis subsp. neglecta $(10.2 \%)$; so T. arvensis subsp. neglecta demonstrating their applicability for medicinal, cosmetic and pharmaceutical purposes with this results. In the present study, the chemical composition of these three important species of the family Apiaceae, commonly used in folk medicine and traditional food flavouring, were characterised by HS-SPME analyzes.

Table I The identified constituents of Torilis arvensis subsp. neglecta (\%)

\begin{tabular}{|c|c|c|c|}
\hline Constituents & RRI* & & $\%$ \\
\hline$\alpha$-pinene & 1035 & 1.8 & \\
\hline Camphene & 1068 & 1.9 & \\
\hline$\beta$-pinene & 1120 & 1.7 & \\
\hline Sabinene & 1130 & 2.5 & \\
\hline$\delta$-3-carene & 1145 & 1.2 & \\
\hline Myrcene & 1163 & 0.5 & \\
\hline$\alpha$-phellandrene & 1180 & 1.2 & \\
\hline$\beta$-phellandrene & 1214 & 1.1 & \\
\hline$\beta$-ocimene & 1305 & 0.4 & \\
\hline$\gamma$-Terpinene & 1348 & 0.1 & \\
\hline$p$-cymene & 1360 & 0.1 & \\
\hline Terpinolene & 1370 & 0.4 & \\
\hline$\alpha$-copaene & 1456 & 1.3 & \\
\hline$\alpha$-cubebene & 1463 & 0.7 & \\
\hline Linalool & 1475 & 0.4 & \\
\hline Bornyl acetate & 1478 & 1.2 & \\
\hline$\gamma$-elemene & 1483 & 2.1 & \\
\hline$\alpha$-copaene & 1490 & 0.3 & \\
\hline$\beta$-cubebene & 1540 & 2.2 & \\
\hline$\delta$-cadinene & 1575 & 3.5 & \\
\hline$\beta$-caryophyllene & 1600 & 10.2 & \\
\hline$\beta$-farnesene & 1615 & 18.5 & \\
\hline$\gamma$-Muurolene & 1702 & 1.7 & \\
\hline germacrene D & 1715 & 1.8 & \\
\hline$\delta$-Cadinene & 1760 & 1.2 & \\
\hline$\beta$-Sesquiphellandrene & 1775 & 0.4 & \\
\hline Caryophyllene oxide & 1989 & 1.2 & \\
\hline Spathulenol & 2120 & 29.2 & \\
\hline$\alpha$-bisabolol & 2210 & 0.2 & \\
\hline$\alpha$-cadinol & 2240 & 0.2 & \\
\hline Pentadecanoic acid & 2920 & 0.1 & \\
\hline *RRI: Relative Retention Index & Total & 88.3 & \\
\hline
\end{tabular}




\section{Conclusion}

In conclusion, the present work is the first report on the composition of essential oils obtained from the aerial parts of T. arvensis subsp. neglecta from Bingöl (Turkey). Comparison of our T. arvensis subsp. neglecta results with the literature showed significant differences for the extracts which can be attributed to different analysis method, either due to climatic, factors or genetic differences of the plants. The biologic activity of $T$. arvensis subsp. neglecta may be related to its richness in secondary metabolites, especially essential oils. Spathulenol, $\beta$-farnesene and $\beta$-caryophyllene were found to be the chemotypes of studied sample.

\section{Acknowledgments}

The author thank the financial support from the Bingol University Scientific Research Project Unit, Bingol/Turkey, Project no. PikomBitki-2018.004.

\section{Conflicts of interest}

Author declares that there is none of the conflicts.

\section{References}

1. Judd WS, Campbell CC, Kelogg EA, et al. Plant systematics: A phylogenetic approach. 3rd ed. USA. 2007. 677 p.

2. Davis PH. Flora of Turkey and East Aegean Islands. Edinburgh: University Press. 1972;11:4.

3. Stevens PF. Angiosperm Phylogeny Website, Version 9. 2008.

4. Ozhatay N, Kultur S. Check-list of add. taxa to the supp. Flora of Turkey III. Turkish Journal of Botany. 2006;30:281-316.

5. Ozhatay N, Kultur S, Aslan S. Check-list of additional taxa to the supp Flora of Turkey. Turkish Journal of Botany. 2009;33:191-226.

6. Ozhatay N, Kultur S, Gurdal MB. Check-list of additional taxa to the supp. Flora of Turkey. Journal of Botany. 2011;35:589-624.

7. Hegnauer R. Chemotaxonomy of plants: an overview of the distribution and systematic significance of plant materials. In: Bd 6, Dicotyledoneae: Rafflesiaceae-Zygophyllaceae. 1973.

8. Gijbels MJM, Scheffer JJC, Baerheim A, et al. Flavourings: Production, Composition, Applications, Regulations. 2nd ed. Itally: Essenze. 1979;8:331-335

9. Plunkett GM, Downie SR. Major lineages within Apiaceae subfamily Apioideae: a comparison of choloroplast restriction site and DNA sequence data. American Journal of Botany. 1999;86(7):1014-1026.

10. Tepe B, Donmez E, Unlu M, et al. Antimicrobial and antioxidative activities of the essential oils and methanol extracts of Salvia cryptantha and Salvia multicaulis. Food Chemistry. 2004;84:519-525.
11. Sacchetti G, Maietti S, Muzzoli M, et al. Comparative evaluation of 11 essential oils of different origin as functional antioxidants, antiradicals and antimicrobials in foods. Food Chemistry. 2005;91:621-632.

12. Burt S. Essential oils: Their antibacterial properties and potential applications in foods-A review. International Journal of Food Microbiology. 2004;94(3):223-253.

13. Pae $\mathrm{HO}$, Oh $\mathrm{H}$, Yun $\mathrm{YG}$, et al. Imperatorin, a furanocoumarin from Angelica dahurica, induces cytochrome c-dependent apoptosis in human promyelocytic leukaemia, HL-60 cells. Pharmacology and Toxicology. 2002;91(1):40-48.

14. Youn JH, Lakritz J, Rottinghaus GE, et al. Anti-protozoal efficacy of high performance liquid chromatography fractions of Torilis japonica and Sophora flavescens extracts on Neospora caninum and Toxoplasma gondii. Veterinary Parasitology. 2004;125(3-4):409-414.

15. Güzel Y. Türkiye'nin Torilis Adans (Apiaceae) cinsine ait türlerin revizyonu ve fitokimyasal analizi, Doktora tezi, Mustafa Kemal Üniversitesi, Fen Bilimleri Enstitüsü, Antakya/HATAY. 2009.

16. Bigdeli M, Rustaivan A, Masoudi S. Composition of the essential oil of Torilis arvensis from Iran. Journal Essential oil Research. 2004;16(6):526527.

17. Verzera A, Zıno M, Condurso C, et al. Solid-phase microextraction and gas chromatography/mass spectrometry for the rapid characterisation of semihard cheeses. Analitical Bioanailtic Chemistry. 2004;380(3-4):930-936.

18. Van Den Dool H, Kratz PD. A generalization of the retention index system including linear temperature programmed gas-liquid chromatography. Journal Chromatography. 1963;11:463-471.

19. Saad HEA, El-Sharkawy SH, Halim AF. Composition of the essential oils of the leaves and stems of Torilis aruensis. Pharmaceutics Acta Helvetiae. 1995;70(1):85-87.

20. Croteau R, Kutchan TM, Lewis NG. Natural products (secondary metabolites). Biochemistry \& Molecular Biology of Plants. $2000 ; 1250-1318$.

21. Masoudi S, Fathollahi R, Taherkhani M, et al. Volatile Constituents of the Aerial parts of Torilis leptophylla (L.) Reichenb., Thecocarpus meifolious Boiss, Leaves of Xanthogalum purpurascens Ave. Lall. and Flowers of Astrodaucus orieintalis (L.) Drude. Four Umbelliferae Herbs from Iran. Journal Essential Oil Bearing Plant. 2012;15(6):934-942.

22. Asakawa Y, Toyota M, Ishida T. Biotransformation of 1,4-cineole, a monoterpene ether. Xenobiotica. 1998;18(10):1129-1134.

23. Debarber AE, Bleyle L, Roullet JB, et al. Omega-Hydroxylation of farnesol by mammalian cytochromes P450. Biochemical Biophysics Acta. $2004 ; 1682: 18-27$. 